\title{
The Limits of Self-Determination and the Cases of Forced Separatism: The Example of Northern Cyprus
}

\author{
Andreas Yfantidis \\ Department of International \& European Studies, University of Piraeus, Piraeus, Greece \\ Email: ayfantidis@yahoo.com
}

Received 11 June 2015; accepted 11 April 2016; published 14 April 2016

Copyright (C) 2016 by author and Scientific Research Publishing Inc. This work is licensed under the Creative Commons Attribution International License (CC BY). http://creativecommons.org/licenses/by/4.0/

(c) (i) Open Access

\section{Abstract}

In the current essay, the writer will try to approach the cases of separatism and especially those of illegal separatism which are creating unrecognized or partially recognized states. It is true though that these cases, even of forced separatism, are matter which has been subjected to the international law and mainly to the principle of the security of a minority group and finally the right to self-determination. Although the principle of self-determination is respected under the Charter of the United Nations (article 1§2), it is still rather vague to define what kind of group is subjected to it. The Charter doesn't provide much information about it and keeps the Wilsonian concept of "self-determination for people", therefore cases of separatism are still under broad and heated debate. Although this paper will focus on the case of forced separatism in Cyprus and especially the case of Northern Cyprus, which has been separated from the Cypriot mainland after the Turkish invasion of $20^{\text {th }}$ July 1974 and has proclaimed to be the independent "Turkish Republic of Northern Cyprus" 1 after 1983. Moreover I will try to focus on the aspects of the separatist arguments posed from the Turkish community for protection from the Greek paramilitary forces and the fact of the invasion which made the whole territory an occupied territory (S/RES/550, 1984) rather than an independent state coming from a legitimate secessionist movement. Hence the arguments and the methodology followed in this paper will move in a dialectic path by highlighting first of all the historical aspects of the case of Cyprus from 1878 and the British rule over the island. Afterwards we will mention the arguments supporting the cases of legitimate secessionism and we will attempt to give a possible definition of illegal and forced separatism which are carried out after invasions and territorial claims that are made under the safeguard clause of the United Nations Covenant of Friendly relations of 1970 . These claims are tightly connected to the-so called but disputable remedial right to secessionism. The remedial right of secessionism is pleaded when the central government is adopting a discriminatory behavior against to a minority group with specific religious or racial characteristics by following strict political, economic and social policies

${ }^{1}$ Kuzey Kıbrıs Türk Cumhuriyeti in Turkish language. 
on this community (Buchanan, 1997).

Keywords

Separatism, International Community, United Nations, Interventionism, Cypriot Issue

\section{Introduction}

Cyprus was part of the Ottoman Empire after the Ottoman-Venetian war of 1570 as an Eyelet ${ }^{2}$ till 1878 and when the British Empire signed the Cyprus convention during the Congress of Berlin with the Ottoman side which assigned Cyprus as a protectorate to British Empire with the return of political and military support of Britain to Ottomans in the case that Russia would attack and annex Ottoman provinces in Asia (such as Kars, Batum and Ardahan) (Annex to Convention of Defensive Alliance, Gr. Br-Trk, 1878). After the declaration of war from Britain to Ottoman Empire in $5^{\text {th }}$ October 1914, the crown annexed Cyprus and in the Treaty of Lausanne on $24^{\text {th }}$ July 1923, the newly formed Republic of Turkey recognized full sovereign rights of Britain on Cyprus (article 20) and in 1925 Cyprus officially became "colony of the Crown" and afterwards the story of the two communities (Greek and Turkish) is starting.

The demographic facts coming from the British side concerning the period show that in $1881,95 \%$ of the Muslim population was Turkish speaking, although the $73.9 \%$ of the whole island's population was Greek and only the $24.4 \%$ was Turkish (Hatay, 2007). But in 1920, a year of great changes in the Greek-Turkish relationship due to the invasion of Greek army to Minor Asia one year before, a lot of Muslims migrated to Turkey and asked for Turkish citizenship for 2 main reasons. The first was the fact that they were abandoned from the official project of nation building in Cyprus and the other was that they wanted to participate in the reform era of the Kemalist regime. After the annexation of Cyprus from Britain the Greek population of the island starting to develop and reached a number of 244,887 when the whole population of the island was 310,000 . It was an increase of $5 \%$ of the Greek community while the Turkish community dropped to $19.6 \%$ of the whole population (Chatzilira, 2009).

The story of the two communities is the most important as it indicates the procedures of nation-building in Cyprus as well as the attempts from the Greek community to maintain control over the island, be independent from the British crown and chase the possibility of uniting with the Kingdom of Greece under the motto of Eno$\mathrm{sis}^{3}$. The case of the Greek Cypriot community is much closer to cases of secessionism subjected to remedial rightscompared to the Turkish Cypriot claims that we will check later (Buchanan, 1997). The revolutions and mainly protests took place in October 1931 (Oktovriana) when the Greek community opposed to the British government under the leadership of the Archbishop Kitios Nikolaos, the MP Stavros Stavrinakis and the ambassador Zinon Rossidis. The British government responded negatively to the self-determination claims of the Greek community and the Greek people believed that this was a pure act of repression of the right for self-governance and self-determination in their own territory. Although these events took place in Cyprus, the international context was against Greece and a possible unification of Cyprus with Greece. After the Minor Asia war ended with the military loss of Greece from Turkey and a series of events till 1932, it was impossible either for the Greek community of Cyprus or even for the Greek government to make any further claims which would be against the interest of the British Empire, as they were the biggest economical, political and military ally to Greece. Although it was understandable mainly by the Greek Cypriots that the time for independence was close, their hopes became true after the 5-year armed conflict with the British forces during 1955-1959. The paramilitary group of EOKA (Ethinki Organosi Kyprion Agoniston) organized from the Greek general G. Grivas was the main resistance force against the British authority. On the other hand, the Turkish side also created a paramilitary force that kept close ties with the Turkish army under the name "Volkan" which later on was renamed as Turkish Resistance Organization (TMT). These two groups played a significant role in the future formation of the

${ }^{2}$ Cyprus was part of the Serenissima Republica di Venezia when Turkish raids to the island begun from 1489 till the late $16^{\text {th }}$ century. Even when the Ottoman fleet was defeated in the Battle of Lepanto, the island of Cyprus had fallen in the hands of the Ottoman Empire.

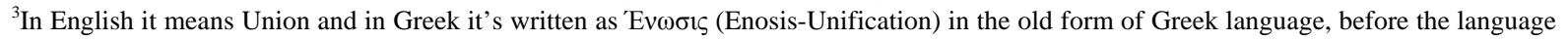
reformation of 1978. This was the main motto and request of the protesters to the British Government. 
two communities as well as in the strict national separation between Greek Cypriots and Turkish Cypriots.

\section{The Political Instability between the Turkish and the Greek Community}

Tensions between the two communities started after the fight for the independence of Cyprus from the United Kingdom which was finally achieved at $16^{\text {th }}$ of August 1960 after the signature of the Tripartite London-Zurich agreements. The so called agreement of Zurich was the base for the Cypriot constitution which although was partially recognized as the island was partitioned in the Greek Cypriot region and the Turkish Cypriot region in 1963 because of the intercommunal violence between the EOKA pro-unionist with Greece paramilitary group and the TMT which was a pro-separatist paramilitary group. The conflict between these two armed groups of the communities many times led to deadly conflicts. After these events the Archbishop Makarios, who was the leader of the Cypriot government, proposed the so called 13 amendments which had been refused by the Turkish side as unacceptable. Even though the constitution had clear provisions about the equality of the two communities there was unrest coming from the Turkish Cypriot community about the leadership and the relations with the Republic of Turkey. Also the Greek side claimed even before these agreements that Turkish Cypriot minority group had too many rights on the governance of the newly existing state (Brinkley, 1989). These tensions were starting to put a lot of obstacles in the bicommunal affairs as both parties were adopting stricter positions on the same issue. Most important attempts happened from the Greek-Cypriots when they pressed under the Archbishop Makarios, who was the head of the Cypriot government, to unify with Greece under the motto of "Enosis". The two main differences between Greek side and Turkish side is exactly the main point of this paper to identify under which circumstances the principle of self-determination is applicable and especially when a proclaimed ethnical team is able to secede from a unitary state by posing its remedial rights to discrimination concerning participation in governance and in important political positions (Carver, 2006). It becomes more and more obvious also that the declaration of the national independence by the side of Turkish-Cyprus was forced under the Turkish government. Turkey has backed up Northern Cyprus with arms and forces during the decolonization process and kept a neutral position when the Greek Cypriots pushed more and more for independence and unification, especially in the years of 1962-1964, when the biggest tensions between the two communities erupted as well as the partition of the island was clear. The southern part was Greek and the Northern part was inhabited by Turkish Cypriots. The informal zone between these two partitions was the "Green Zone" which tried to keep the two communities away from violent acts. And here it's vital to see the two different strategies followed by the two counterparts on the whole issue.

First of all, the Greek Cypriots under Makarios governance tended to look for help in the Soviet Union after Makarios had rejected the US led proposal for sending a peacekeeping force under the NATO coordination in order to deescalate the ongoing crisis between the two communities, especially when the violence was at its highest point in $26^{\text {th }}$ of December in 1963. During this period of time the global system was facing the monolithic "cold struggle" between the East and West powers, and moves like this could easily create a diplomatic crisis between smaller states and USA (or USSR in several cases). This made the Lyndon Johnson's government to state that Cyprus was a "Mediterranean Cuba" (Brinkley, 1989). On the other side, Turkish Cypriots were seeking in help from the Turkish government which kept a mostly western-side friendly position in order to keep smooth in the western alliance and also to have on its side the British and American government. Under these circumstances it is clear that Turkey, after its participation with a huge commitment of troops in the Korean War, wanted to strengthen its position in NATO and moreover to take the control of the Eastern Mediterranean affairs under the US initiative for protectionism of a so vital part for the defence system of NATO. Along with the aforementioned characteristics of the Turkish strategy, which remind us the fundamental parts of the modern Turkish strategy described by A. Davutoglu in his book called "The Strategic Depth"4, it was one of the main goals posed clearly from the Turkish side to keep a buffer zone in its southern border with Greece which would make it easier for their government to make claims in the sea zone around Cyprus (Blay, 1983). Turkey used this as an argument to prove that Cyprus was vulnerable to the Soviet sphere of influence and that such proposals from Makarios were leading to a total dead end. Moreover Turkey didn't intervene at that moment in a direct

\footnotetext{
${ }^{4}$ Ahmet Davutoglu in the Strategic Depth is arguing about Turkish transcontinental role by contrasting it to the role of Russia, as a clearly eastern oriented country. Davutoglu is claiming that Turkey has to have an adjusting role in Asia and especially in Middle East and southern Mediterranean but also has to belong in the Western institutions and in the Western alliances, by keeping a balance between these previous two principles. Anyway the Ottoman Empire has a long story of attempts to reach the Western world, starting from the aftermath of the Crimean War and the article 56 of the Treaty of Paris which "welcomed the Ottoman Empire as a member of the European Concert".
} 
way and attempted to keep a more neutral position by trying to find other ways to back up their community in Northern Cyprus.

Although by the end of 1964 the talks begun again on a different basis, as Dean Acheson, the Secretary of State during the $2^{\text {nd }}$ Truman's governance (1949-1953) was appointed to be the mediator for the Cyprus Question. Dean Acheson came up with a plan which hoped to resolve the ongoing crisis and give a final and viable solution for the peaceful cooperation between the two communities of the island. The so called "Acheson Plans" had 5 main points. The most important was the first one which was fulfilling in a way the claims of Greek Cypriots for unification with Greece (Enosis). Also the other points were suggesting that Turkey would keep a military base in Northern Cyprus (Kyrenia) which would be leased from the Cypriot government and also that the island would be divided in 8 sectors and the 2 of these would belong to the Turkish Cypriot authority, as a part of devolutioned powers to Turkey (Brinkley, 1989). The Acheson plan was accepted by Turkey but the Greek side rejected it without second thought. One can say that it was of pure madness to reject a plan which was leading to the unification of Cyprus with Greece. But Archbishop Makarios had predicted that this plan was leaving the door opened to a possible Turkish invasion to the island from the military base and it would lead to a total destruction of the Greek community. Also the Acheson planed had been criticized as an attempt carried by the USA government to keep the Soviet Union out of their interest zone and by that creating a plan which was an instrument of Realpolitik. The Acheson plan was putting the US interest, which was and currently is a global power, in Eastern Mediterranean above the other two "small states” interest and was totally putting in second place the fate of the people of the two communities. Moreover Makarios saw this again as a trap from NATO, because of the previous conclusions and therefore he rejected the plan, which was later called as the "lost chance for a final settlement between the two communities" as Turkey was willing to reach to a total concession for the first time (Nawaz, 1989).

\section{The Turkish Invasion and the Illegal Declaration of Turkish Cyprus as an Independent, Self-Governed State}

As the escalation of the crisis was going on and the plans for finding a sustainable solution were failing the one after the other, the only way that problems are solved in international relations seemed to be also the only way for coping with the case of bicommunal violence and this was war. After the military dictatorship of 1967 in

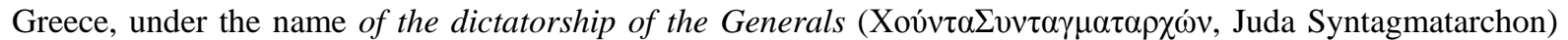
from G. Papadopoulos, S. Pattakos and N. Makarezos the case of Cyprus seemed to lead to a total dead end. The crisis went further on when the Cypriot National guard under General Grivas attacked a Turkish Cypriot village and lead to further escalation of the crisis between Greece, Cyprus and Turkey. It was only in 1968 that the tensions begun to relax when an agreement for a ceasefire came into force and general Grivas was sent back to Greece. In 1971 he returned secretly in Cyprus and formed the paramilitary group EOKA-B, as he tried to complete the total unification with the use of arms by also trying to overthrow Archbishop Makarios from President of Cyprus. The case of Cyprus after this move from Grivas led to the total destruction of the relations between Greek Cypriots and Turkish Cypriots as also a Turkish invasion was imminent. Truly the invasion happened 3 years later in 1974 when the military dictatorship in Athens was overthrown after the dictator's Ioannidis attempt for a further coup d' etat (Uslu, 2003) against the previous dictator, G. Papadopoulos. In July 1974 the Turkish army invaded the island and took over the 38\% of Cyprus, mainly the Northern Cyprus by claiming the protection of the Turkish minority rights and their fundamental right to self-determination and self-governance. Turkey under Prime Minister Ecevit announced in 8.30 am of $19^{\text {th }}$ July 1974 the invasion of the island of Cyprus in order to "bring peace not only to the Turks but also the Greeks" (Carver, 2006). The invasion ended soon and Northern Cyprus was proclaimed as an independent state. The stationed troops of UNFICYP (S/RES/186, $1964)^{5}$ from 1965 tried to deescalate the crisis and protect the two communities but their attempts weren't enough. A lot of Greek Cypriots died in the days of the invasion and moreover a lot were forced to leave their homes and flee to the Southern part of Cyprus. The invasion gave an end to the military dictatorship in Athens as well also destroyed the dreams for unification with Greece. Cyprus was from now on "a state of two states”, of which the one was a case of illegal and forced separatism carried out from the invasion of an external actor.

\footnotetext{
${ }^{5}$ United Nations Peacekeeping Force in Cyprus was the peacekeeping force established under the United Nations Security Council resolution 186/1964 under the article 4, with the title "The Cyprus Question" after the eruption of the intercommunal violence. The UNFICYP was a joint military peacekeeping force which replaced the British Forces which used to have the role of the peacekeeper from 1959 under the Zurich-London agreements.
} 
In $15^{\text {th }}$ of July 1983 the separatist movement of the Turks of Northern Cyprus proclaimed its independence from the Cypriot government by declaring its own self-governance as well as the name of the new political entity was "Turkish Republic of Northern Cyprus" and this entity was seeking for international recognition. The Security Council after these moves carried out by the Turkish side, which were clearly breaching article 2 par. 4 of the United Nations Charter as well as the Tripartite Agreements of 1960, once again took decisions by condemning these actions carried out by Turkey and by adopting the Resolution 541 (S/RES/541, 1983) and later on the Resolution 550 which prohibited the official recognition of the "Turkish Republic of Northern Cyprus" as an independent and self-governed state (S/RES/550, 1984). From the year 1983 and till now the question of Cyprus came into a new era. For many people this question seems to be a "frozen" one and the solutions proposed are rejected either by the Greek or by the Turkish side.

A new mediation attempt started in 1999 when Kofi Annan came up with a plan of uniting the two political entities in a new state called the "United Republic of Cyprus". Kofi Annan, who was the Secretary General of the United Nations at the moment drafted a plan which had as its goal the creation of a federal republic consisting of two states, as this was based loosely on the Swiss federal model and it was also inspired by the way that the two communities in Bosnia \& Herzegovina are currently coexisting. The Anan plan 1 and 2 failed after the rejection of the Turkish Prime minister of Northern Cyprus, Rauf Denktash, to come to a $6^{\text {th }}$ round of talks with the Greek Cypriot leader, Glafkos Klerides (S/2003/398, 2003). More negotiations took place in the context of the Anan Plan $1 \& 2$ in 2003, when Kofi Anan came up with the $3^{\text {rd }}$ plan (Anan, 2004) concerning the settlement of the Cypriot dispute. The third plan was giving full autonomy to the Turkish Cypriots and it was establishing a bicommunal and bi-zonal federal Republic with a joint legislature and government. The Anan plan 3 was rejected from the $76 \%$ of the Greek Cypriots after a referendum held from the administration of Tassos Papadopoulos, the President of the Republic of Cyprus. Mr. Papadopoulos after a famous speech in which he gave in $7^{\text {th }}$ of April of 2004 called the Greek Cypriots to refrain from voting yes to the Anan plan as this would destroy the independent nation of Cyprus and it would divide it in two communities. Especially he mentioned that "I received an independent and self-governed state. I can't give back an autonomous community!" 6 The Anan plan of 2004 failed like the previous two as well as the older plan of Dean Acheson and now the Cyprus question seems to remain unsolved.

\section{Is the Case of Northern Cyprus an Acceptable and Legitimate Case of Secessionism under the Remedial Rights Case?}

After the extended analysis about the Northern Cyprus separatist case and the dispute with the Greek Cypriots which followed and other path of separatism in the middle of $20^{\text {th }}$ century, it's obvious what arguments each side used in order to support its actions towards the whole dispute.

First of all as I mentioned in the introduction part of this paper, the method which I follow is the path of the dialectics, in order to define the legitimate cases of secession, to highlight the main arguments used by each side and finally to divide cases of legal secessionism from cases of illegal and forced secessionism. In the case of Cyprus, things are too complicated but we can be sure about only one thing. There was no agreed secession in both cases of separatism from the British Empire in 1959 and the forced separatism of Northern Cyprus from the Cypriot mainland in July 1974. Hence it's clear that both sides used disputable meanings and interpretations about the self-determination concept and the following creation of a new, self-governed and independent state.

The case of separatism in 1959 was clearly based in a combination of special remedial and primary rights of a group to self-determination and this group posed the ascriptive arguments to support it. As Ross explained and Nawaz wrote, the right of self-determination is "a right of a people or a group to determine the national dependency of the territory inhabited... could be ceded unless confirmed by a plebiscite" (Nawaz, 1989). In the case of the EOKA anti-British campaign, we can clearly see the ascriptive arguments, e.g. the motto Unification (Enosis) or the use of national symbols which connected the "Motherland" (Greece) with Cyprus etc. and even the attempts of the Greek government to chase a chance for independence and unification with Cyprus ${ }^{7}$. Moreover in $29^{\text {th }}$ July 1960, the British Parliament under a Labor government ratified a bill of giving independence to

\footnotetext{
${ }^{6}$ Center of Studies "Tassos Papadopoulos" (2014). Center of Studies "Tassos Papadopoulos"-The Historical Address of the President of the Republic, Tassos Papadopoulos. Available at: http://www.tassospapadopoulos.com/easyconsole.cfm/id/100

${ }^{7}$ Cyprus and Greece share a common history of hundreds of years. Except from the fact that Greece and Cyprus shares a common language (the most common ascriptive argument), they also share common anthem and common national holidays. The relation between the two states is a very special and unique case of a "united" but not unified political entity.
} 
Cyprus by keeping the two sui generis Sovereign Base Areas, in order to ensure its presence in eastern Mediterranean Sea. Moreover the Greek-Cypriot campaign for independence erupted at the beginning of the decolonization era, when the opinions about the self-determination concept were giving to the existing colonies the right to secede from an existing territory and claim their independence and self-governance (e.g. India and Pakistan in 1947). Cyprus, as we have seen in section no. 2, after the Lausanne treaty and the additional protocol, was named as a "colony of the British crown" and therefore during the decolonization process the Cypriot political entity was recognized to have the same rights to self-determination, independence and secession as all the other states under colonial occupation (Nawaz, 1965). Therefore the case of Cyprus independence after the EOKA campaign has clear signs of a special remedial secessionism, which is although put in a context of a specific agreement which was signed in the tripartite convention of Zurich-London agreements in 1959-1960 and was also ratified in the British parliament (The parliament of the existing state).

On the other hand, the case of Turkish separatist movement in 1974 and the claims for partition (Taksim) from the era of the intercommunal violence till the final violent partition of Cyprus in the Southern and recognized state and the Northern unrecognized puppet state, have major differences with the first case of separatism.

First of all the most important breach and difference between the first case and second case is the fact of the invasion. As we have seen many times in recent history invasions happen in the name of the protection of human rights and minority's group rights to self-governance. These kinds of interventions are the so called "Humanitarian Interventions” (Goodman et al., 2007) and their role in international politics is still under heavy dispute. The Turkish invasion on the island is denounced in all the Security Council Resolutions after 1974 as a breach to the article 2 par. 4 of the United Nations charted and of article 3 of the Geneva charted of Human rights of 1949 which prohibited intervention of an external factor, therefore the TRNC is an illegal political entity and especially an "occupied part of Cyprus". Moreover the concept of self-determination in the case of Northern Cyprus is rather vague and obscure contrary to the decolonization process which started to happen after the end of World War 2. Turkey and Turkish Cypriots founded in 1958 a unilateral committee of observation of breaches to the Cypriot constitution and after several reports they observed severe discrimination in the proportionality of votes in the Cypriot Assembly as well as extreme violence carried out by the Greek Cypriot's police. Albeit the proportionality is an invalid argument as the document which validated this was part of the tripartite convention signed in 1959 in Zurich and moreover it is described in the Appendix A, under the name "Basic structure of the Republic of Cyprus”. The second argument about extreme violence is hiding a truth fact about raids carried out from the Greek Cypriots, during an era of intercommunal violence. Moreover the violence which led to 56 dead Greeks and 53 Turks (Loizos, 1988) is connected more sentimentally to a case of self-determination rather than implying a rational criterion for the self-determination of Northern-Cyprus. Last but not least is the case of the constitutional crisis after 1963 when Makarios proposed the amendments to the Cypriot Vice president, after he exercised his veto power in a law about levying taxes. The rejection of the 13 points led to further escalation of the crisis and gave to the Turkish community the remedial argument of "discrimination in the distribution of resources" (Buchanan, 1997).

As it is clear from the present analysis, the two cases of separatism have a very different context in which they happened and moreover both communities used totally different means in the way that they achieved their independence. The difference in the means highlights exactly the different approach in the whole issue based on international law, human rights or realpolitik and use of power. Further research can show more specifically the way that self-determination was used in the case of Northern Cyprus and how it was connected to the self-claimed remedial rights of Turkish Cypriots on secessionism from the mainland. But the main fact till now is that Northern Cyprus is a state recognized only by Turkey and the international community still accepts the fact that Northern Cyprus is under occupation of a huge portion of the Turkish army and navy.

\section{References}

Anan, K. (2004). The Comprehensive Settlement of the Cyprus Problem.

http://www.mfa.gov.tr/un-comprehensive-settlement-plan-of-the-cyprus-question.en.mfa

Annex to Convention of Defensive Alliance, Gr. Br-Trk, June 4, 1878.

Blay, S. K. N. (1983). Self-Determination in Cyprus. The Dimensions of an Old Conflict. Australian Year Book of International Law, 10, 67-100.

http://aspects.duckdns.org/cyprus/documents/198907_The-Cyprus-Question-Dean-Acheson-as-Mediator_by_Douglas-Bri 
$\underline{\text { nkley.pdf }}$

Brinkley, D. (1989). The Cyprus Question: Dean Acheson as Mediator. Journal of the Hellenic Diaspora, 15, 5-18.

Buchanan, A. (1997). Theories of Secession. Philosophy \& Public Affairs, 26, 31-61. http://dx.doi.org/10.1111/j.1088-4963.1997.tb00049.x

Carver, M. (2006). The Gordian Knot: American and British Policy Concerning the Cyprus Issue: 1952-1974. Electronic Thesis or Dissertation. https://etd.ohiolink.edu/

Center of Studies “Tassos Papadopoulos” (2014). Center of Studies “Tassos Papadopoulos”-The Historical Address of the President of the Republic, Tassos Papadopoulos. http://www.tassospapadopoulos.com/easyconsole.cfm/id/100

Chatzilira, A. (2009). The Armenians of Cyprus. Nicosia: Kalaydjian Foundation, 20-21.

Goodman, R., Alford, W., Barron, D., Braman, D., Cavallaro, J., Guzman, A., \& Seeley, S. (2007). Humanitarian Intervention and Pretexts for War. The American Journal of International Law, 100.

http://www.law.harvard.edu/faculty/rgoodman/pdfs/RGoodmanHumanitarianInterventionPretextsforWar.pdf

Hatay, M. (2007). Is the Turkish Cypriot Population Shrinking? An Overview of the Ethno-Demography of Cyprus in the Light of the Preliminary Results of the 2006 Turkish-Cypriot Census. International Peace Research Institute, 64.

Loizos, P. (1988). Intercommunal Killing in Cyprus. Man, 23, 639. http://dx.doi.org/10.2307/2802597

Nawaz, M. (1965). The Meaning and Range of the Principle of Self-Determination. Duke Law Journal, 1965, 82-101. http://dx.doi.org/10.2307/1371019

S/RES/186 (Security Council resolution 186/64) (1964). the situation in Cyprus.

S/RES/541 (Security Council Resolution 541/83) (1983). The Situation in Cyprus.

S/RES/550 (Security Council resolution 550/84) (1984). The Situation in Cyprus.

S/2003/398 (2003). Report of the Secretary General of the United Nations on His Mission of Good Offices in Cyprus. United Nations, 2-7.

Uslu, N. (2003). The Cyprus Question as an Issue of Turkish Foreign Policy and Turkish-American Relations, 1959-2003. New York: Nova Science Publishers 